\title{
STRATEGIC PLANNING IN PROCESS OF ADAPTING CITIES TO CLIMATE CHANGE
}

\author{
Anastasiya Les ${ }^{1}$, Anastasia Rashchenko ${ }^{1}$, Nataliya Tsyvenkova ${ }^{1,2}$, Tetyana Les ${ }^{1}$ \\ ${ }^{1}$ Polissia National University, Ukraine; \\ ${ }^{2}$ National University of Life and Environmental Sciences of Ukraine, Ukraine \\ bambina_nas@yahoo.com, a.rashchenko@gmail.com, \\ nataliyatsyvenkova@gmail.com, tetyana.les@gmail.com
}

\begin{abstract}
The article investigates the role of Ukrainian cities in the process of adaptation to climate change on the example of the city of Zhytomyr. Studies of ambient temperature in summer and winter show deviations of their actual values from climatic norms within $5.3{ }^{\circ} \mathrm{C}$ and $5.8^{\circ} \mathrm{C}$, respectively. The deviation of the average monthly temperature from the climatic norm for the period 2018-2019 was up to $30 \%$. Due to this, the number of days with the temperature above $30{ }^{\circ} \mathrm{C}$ increased by 18 over the last 30 years. The role of society in the process of adaptation of the city to climate change was studied by surveying 588 respondents $(51.0 \%$ men and $49.0 \%$ women aged 20 to 60 years) living in Zhytomyr. As a result of the survey, it was established that the majority of the respondents (88\%) are concerned about climate change, which has been observed in recent years (2018-2019). Only $77 \%$ of 588 respondents attribute the causes of climate change on the planet in general and in Zhytomyr in particular to human activities. Climate change, according to the respondents, will lead to drought (30\%), lack of drinking water (18\%), natural disasters (21.4\%) and cause irreparable damage to agriculture (23.6\%). $20 \%$ of the respondents are ready to take an active part in measures to adapt the city to climate change. Based on the results of the sociological survey, the Zhytomyr climate strategy project was developed, which was successfully tested in Zhytomyr, and the need for its development was indicated in the "Strategy Zhytomyr 2030". Based on the climate strategy project, a conceptual model of the city's climate strategy formation has been developed. It includes four stages of implementation: initiation and research; development of the strategy; adoption and implementation of the strategy; monitoring and control. The model can be a guide for writing the same strategic documents for other cities in Ukraine.
\end{abstract}

Keywords: climate change, adaptation, city, climate strategy.

\section{Introduction}

Scientists have proved the fact of climate change on the planet $[1 ; 2]$. According to the Goddard Space Research Institute, the average world temperature has risen by $0.9^{\circ} \mathrm{C}$ over the past hundred years. Warming is caused by human anthropogenic activity [3; 4]. The upper limit of global temperature rise, as enshrined in international agreements, makes $2^{\circ} \mathrm{C}$, and the mark to which the world community should go is $+1.5^{\circ} \mathrm{C}$ [5]. According to IPCC 2018 average global temperatures above these limits will have negative consequences [5]. Research results published by Climate Central show that, if the global temperature of the Earth rises by $4{ }^{\circ} \mathrm{C}$, the water level in the oceans will rise by almost 9 meters [5]. At current rates of social development, this forecast can come true in about 100 years [5]. The consequence may be that most of the territories of Europe as a whole, as well as Ukraine in particular, could potentially go underwater.

Since Ukraine is a part of several international agreements (the UN Framework Convention on Climate Change) [6], in particular, the Kyoto Protocol [7] and the Paris Agreement [8]), measures aimed at ensuring low-carbon development, transition to renewable energy sources, reducing energy consumption are actively implemented. To prove this, a number of regulatory documents have been adopted in Ukraine - Association Agreements between Ukraine and the European Union [9], the European Atomic Energy Community and their Member States [10], the concept of implementation of state policy in the field of climate change for the period up to 2030 [11]). Their implementation is entrusted not only to public authorities. It is assumed that certain components of state climate policy should be taken into account in the development programs and plans of regions, cities, and towns. An example of the implementation of such programs is the Lviv region, which is due to the wider cooperation with the EU countries and their climate practices [12]. It is obvious that the effects of climate change will intensify. Therefore, it is important to develop an action plan for the adaptation of areas to climate change.

Various weather conditions and growing risks associated with climate change are shown in numerous studies [5;13]. The importance of the nexus of climate change adaptation and socioeconomic 
variables is proved [4]. The studies of Moss et al. proved that climate change prevention and adaptation decisions should be supported by local communities, especially in the framework of cooperation between authorities, decision-makers, scientists and citizens [14]. The study [3] showed that cities do not encourage the private sector to the adaptation or changing the behavior. At the same time, neighborhood governance and neighborhood-led initiatives are an important and relatively powerful force in city policy and planning processes and provided input and opportunities for adaptation planning efforts [2]. According to Arnott et al., it is not enough to develop an adaptation strategy and action plan, it is important to evaluate the implementation [1]. In addition, as proven by Hackenbruch et al., most small towns and communities are unable to found climate change adaptation experts and offices [15]. Studies [2;3] mention that for a good understanding of the problem, various types of stakeholder involvement in solving problems posed are acceptable. We agree that this issue is relevant.

The purpose of the study is to develop recommendations for the formation of the city's climate strategy. Therefore, the study will focus on the following tasks: to establish compliance of temperature in 2019 with the normative value and trends in the number of days with temperatures above 30 as indicators of climate changes; to determine the attitude of city residents to the problems of climate change by the method of sociological survey; to develop a conceptual model of the city climate strategy formation.

\section{Materials and methods}

\section{Study area}

Zhytomyr is located in the northwestern part of Ukraine and covers an area of about 65 square $\mathrm{km}$. The Teterev River and several small rivers flow through the territory of the city, surrounded by forests. The climate of the city is characterized as temperate continental. Warm, humid summers and mild, cloudy winters are traditionally observed. Zhytomyr was chosen as the object of this study because it has most of the manifestations of climate change typical for cities. In addition, the model for both climate mitigation and adaptation can be scaled to other cities in Ukraine.

\section{Vulnerability of the study area}

Most of the city landscapes are covered with artificial cover, which causes an increase in heat island that results in the increased risk of heat stress. Furthermore, artificial surfaces make it impossible to absorb moisture in a timely manner, as a result we deal with floods. The formation of green areas improves the situation, but does not fully solve it.

A separate problematic issue is energy supply and heating, which produce $20 \%$ of all air pollutants in the city. Nowadays, much attention in Ukrainian cities is paid to solving this problem through energy management and audit. The actualization of energy-saving problems in our country is caused not only by the desire to prevent climate changes, but also by objective economic factors. Over the past five years the cost of the utilities raised by more than ten times. So, people are interested in finding ways to reduce the actual costs.

According to the data of the Department of Ecology and Natural Resources of the Zhytomyr Regional State Administration, vehicles are the main source of air pollution (55\%). Experts from different countries are looking for a balance between mobility and reduction of the load on vehicles. According to [16], the development of pedestrian and bicycle infrastructure of the city is up to date.

\section{Sampling}

The population of Zhytomyr is 264 thousand people. The units of the studied population were men and women aged 20 to 60 years, living in the city of Zhytomyr (163020 people). The sample size is determined by calculating the confidence interval [17]. At the same time, the following initial information was taken into account: 1) the indicator of variation is $50 \%$, since there is no information about such studies, and therefore, the variation is unknown; 2) the normalized deviation is determined to the confidence level of $95 \%$, it is standard for sociological survey and is equal to $1.96 ; 3$ ) the permissible error is $5 \%$.

The sample size $(n)$ is calculated by the formula [17]:

$$
n=\frac{z^{2} \cdot p \cdot q}{e^{2}},
$$


where $z$-normalized deviation;

$p$ - variation for the sample;

$q=(100-p)$

$e$ - permissible error.

As a result of the calculations, it was determined that the survey data of 384 respondents would be representative, however, given the significant size of the general population, the number of respondents was increased to 600 in order to obtain information on the level of awareness of the population about the problems of climate change. The selection of respondents was random. The survey was administered by face-to-face interviews.

\section{Data collection procedure and instrument}

The questionnaire for the survey was designed in 2018. The goal of the survey was to collect data about the sociodemographic profile of the respondents; to determine the degree of concern of the population of Zhytomyr with climate changes; determine the readiness of the population to take part in measures to adapt to climate change. The survey had structured and semi-structured questions. Pilot survey covered 20 respondents as a pre-test in order to identify mistakes and prevent misunderstanding in the questionnaire. We fixed all issues and changed some questions to make it easier to understand. We excluded all the data from the pilot survey from the final analysis.

We also did not use $2 \%$ of answers with missing or unmatched fields, we were left with 588 cases for analysis.

Table 1

Sociodemographic profile of respondents. Total number of respondents were 588

\begin{tabular}{|c|l|c|c|}
\hline Variable & \multicolumn{1}{|c|}{ Categories } & Number of respondents & \% \\
\hline \multirow{2}{*}{ Gender } & Male & 288 & 49.0 \\
\cline { 2 - 4 } & Female & 300 & 51.0 \\
\hline \multirow{2}{*}{ Age } & 39 or younger & 384 & 65.3 \\
\cline { 2 - 4 } & 40 and older & 204 & 34.7 \\
\hline \multirow{2}{*}{ Education } & Secondary Education & 165 & 28.1 \\
\cline { 2 - 4 } & Higher Education & 423 & 71.9 \\
\hline \multirow{2}{*}{ Family } & Not Married & 410 & 69.7 \\
\cline { 2 - 4 } & Married & 178 & 30.3 \\
\hline \multirow{2}{*}{ Kids } & No Kids & 465 & 79.1 \\
\cline { 2 - 4 } & 1 ore more kids & 123 & 20.9 \\
\hline
\end{tabular}

Model explanation

The questionnaire for our survey was developed using binominal logistic regression. It means that in all questions the dependent variable was nominal. While examining how socioeconomic variables influence the awareness and readiness to adapt to climate change, we explored situations in which the observed outcome for a dependent variable could have two types, "0" and "1". For example, "Do you have kids in a family?" has two possible answers, "yes" (1) vs. "no" (0).

\section{Exploring the adaptation measures}

The questionnaire included four questions: \#1 "Are you concerned about climate?"; \#2 "What are the reasons of climate changes?"; \#3 "What consequences of climate change do you feel?"; \#4 "Would you like to participate in the development and implementation of an action plan for adaptation of Zhytomyr to climate change?". The data obtained as a result of the conducted sociological survey were entered into the computer program SPSS [18] with the help of which they were processed and analyzed.

The empirical material of the study is the opted climatic indicators for the period of 2000-2019 available on the Ukrainian Hydrometeorological Centre (state institution of Ukraine, which in its activities is guided by the regulations and standards of the World Meteorological Organization) and Meteopost (an independent database of meteorological data obtained from open sources). An analysis of the increase in seasonal temperature was carried out by comparing the mean month's temperatures in 2019 with the climatic norms of temperature indicators for 50 years' time period. The tendencies of changes in the number of days with temperatures above $30^{\circ} \mathrm{C}$ were constructed by using the dynamics 
diagrams that allow to analyze the development of phenomena in time. Using in this study data for 30year period, which is determined as climatological standard normal, allowed the investigation of the influence of temperature differences on the cities functioning.

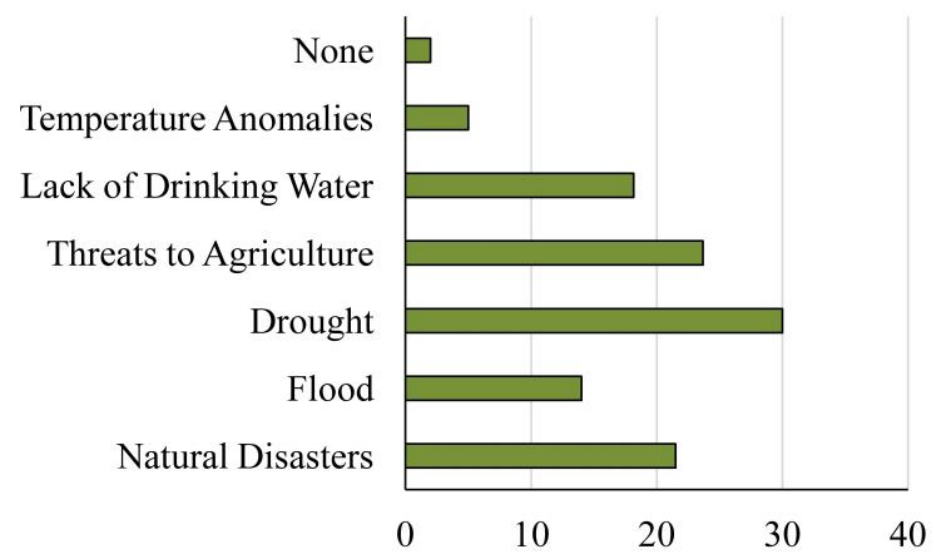

Fig. 1. Consequences of climate change felt by inhabitants of Zhytomyr

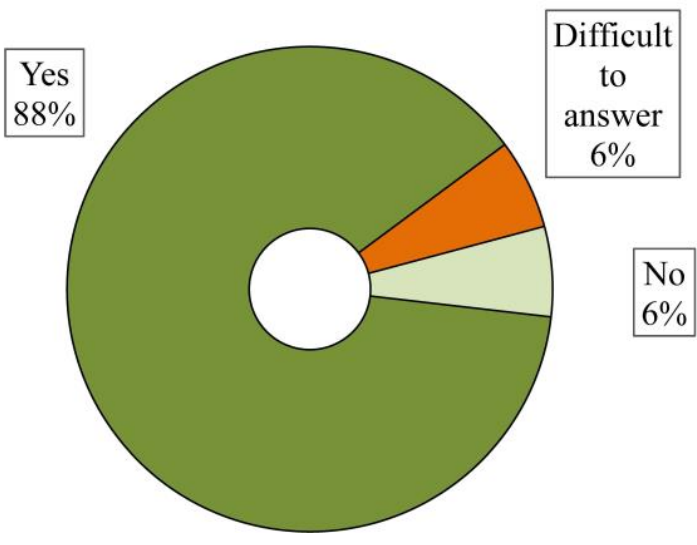

Fig. 2. Percent of people who were concerned about climate change

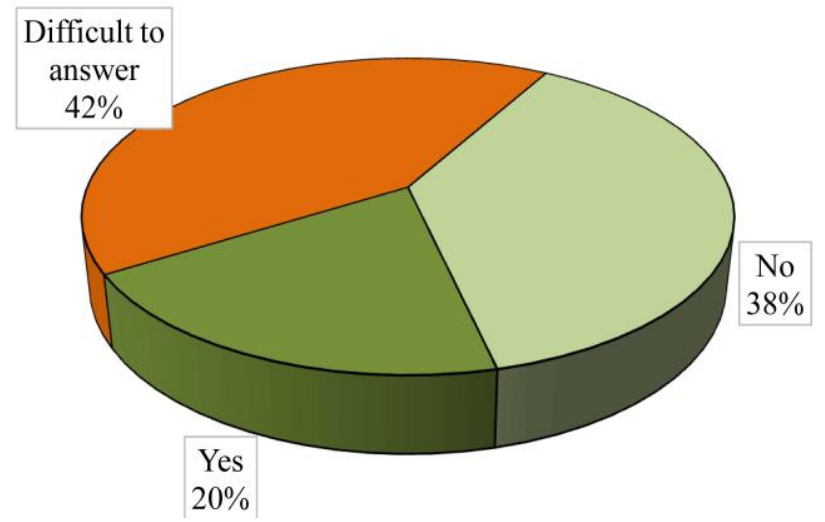

Fig. 3. Percent of people who want to participate in development and implementation of an action plan for adaptation of Zhytomyr to climate change

\section{Socioeconomic profile of the respondents}

The result of the survey was the following demographic profile of the respondents: $49.0 \%$ of men and $51.0 \%$ of women, which roughly corresponds to the distribution of citizens of Zhytomyr by gender. The age structure of the respondents was as follows: 39 or younger $-65.3 \%$ of respondents, 40 and older $-34.7 \%$ of respondents. Most of the respondents had higher education (423 out of 588). The majority of the respondents $(30.3 \%)$ were married and $20.9 \%$ have kids. The obtained sample reproduces the main characteristics of the general population.

\section{Results and discussion}

Considering the fact that climate change and its effects are inevitable, we have identified a specific development benchmark. According to the research results (2018-2019), urban ecosystems are most affected by climate change through a number of factors: population concentration, features of the local microclimate, changes in the prevailing fortification surfaces of the city, high-rise construction, urban transport network and developed infrastructure [20]. We consider the shaping of the city climate strategy as an integral indicator of successful development.

Therefore, the possibility of forming the specified document using the example of Zhytomyr was considered. In the context of this study, an analysis of the increase in seasonal temperature was carried 
out (Fig. 4). As a result of comparing the average monthly temperatures in 2019 with climatic norms (the average temperature for 50 years), it was found that the temperature regime in Zhytomyr has changed. There was an increase in average monthly temperatures throughout the year (in June it was $5.3^{\circ} \mathrm{C}$ higher than the climatic norm; in December and February it was above the climatic norm by 5.4 and $5.8^{\circ} \mathrm{C}$, respectively).

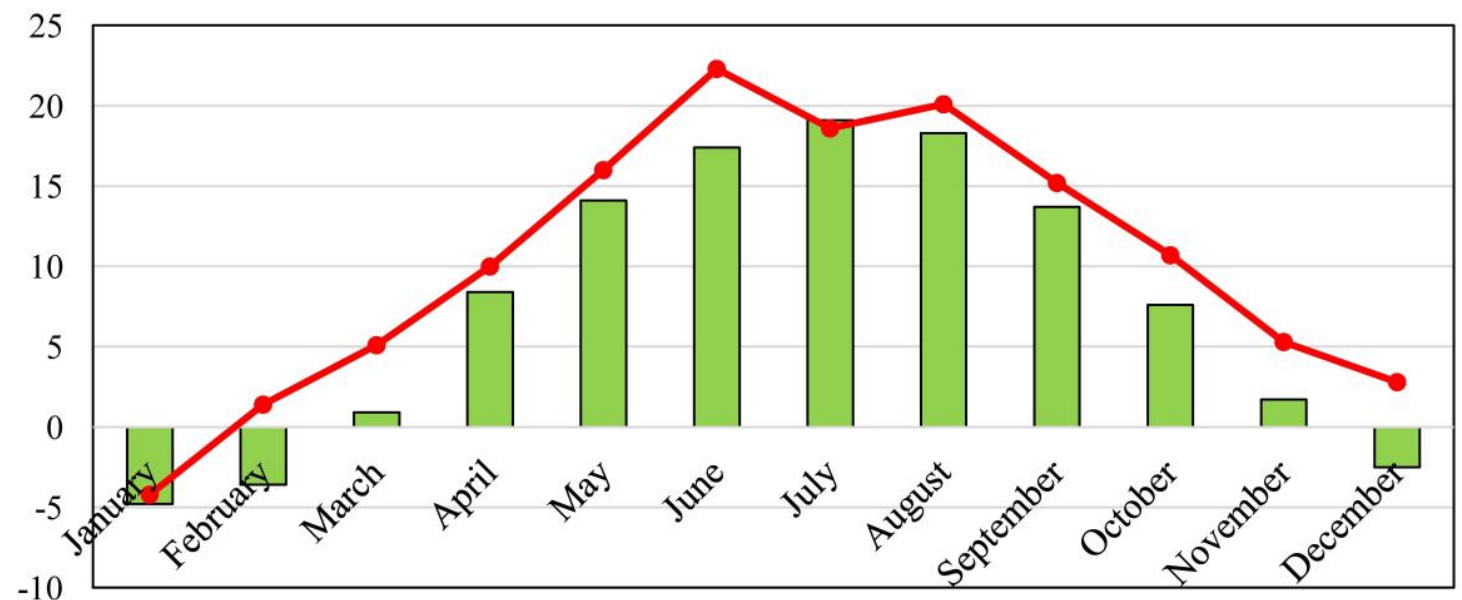

$\square$ Climatic Norms of Temperature Indicators $\quad \longrightarrow$ Mean Month Temperature in 2019

Fig. 4. Deviation of temperature indicators in 2019 from the climatic norms

The tendencies of changes in the number of days with temperatures above $30{ }^{\circ} \mathrm{C}$ were investigated (Fig. 5). The graph clearly shows a tendency towards an increase in hot days per year (air temperature is above $30{ }^{\circ} \mathrm{C}$ ). In Zhytomyr in 2019 there were 18 days with temperatures above $30{ }^{\circ} \mathrm{C}$. The heterogeneity of indicators and the systemic formation of peaks are noted.

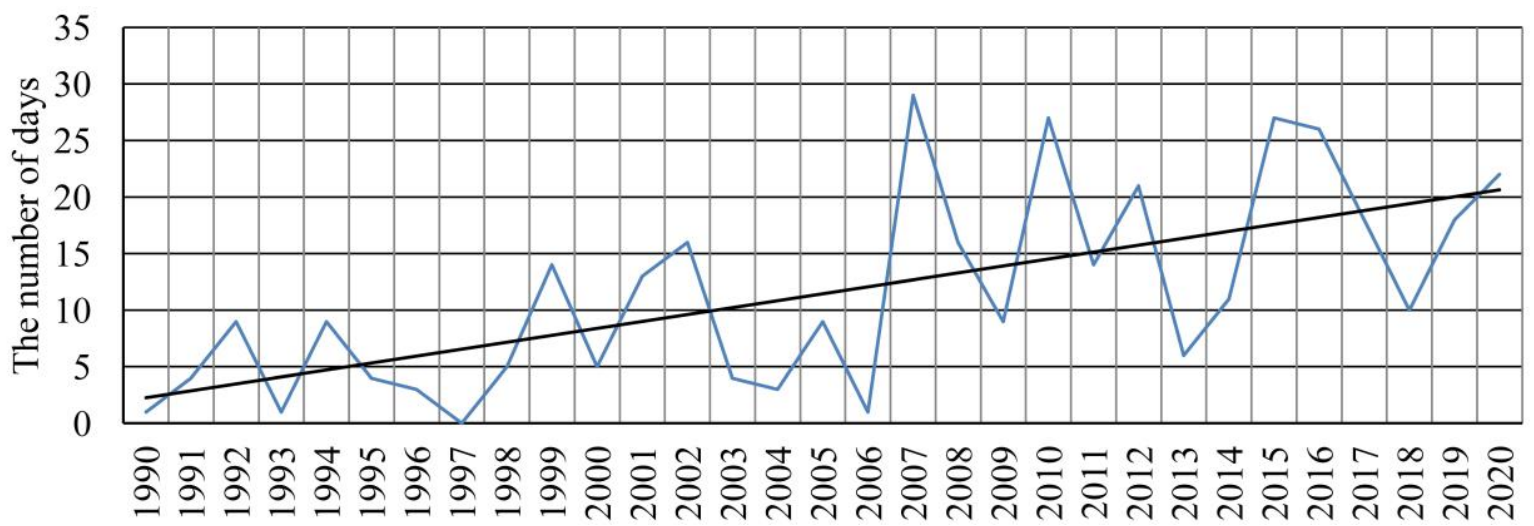

Fig. 5. Quantity of days with the temperature higher than $30^{\circ} \mathrm{C}$

To justify the priorities of the climate strategy a social study was carried out in 2018. As a result of the survey, it was established that the majority of respondents $(88 \%)$ are concerned about climate change, $6 \%$ did not consider the existence of the problem relevant (questionnaire, question \#1).

According to the second question of the questionnaire, the vast majority of respondents (77\%) said they were aware of the causes of climate change on the planet and the involvement of humanity in the process. Only $15 \%$ claim that natural processes cause climate change (questionnaire, question \#2).

According to Fig. 1 (questionnaire, question \#3), the respondents assessed the manifestations of climate change in a rather diverse way. $30 \%$ of the respondents consider drought to be the most urgent consequences of climate change; $23.6 \%$ of the respondents concern about damage to agriculture as a consequence of climate change; $21.4 \%$ of the respondents point out natural disasters as the most pressing impact of climate change; $18.1 \%$ of the respondents consider the lack of drinking water to be the most urgent consequence of climate change.

The majority of the respondents indicated that there were several effects of climate changes at once; some respondents indicated that they did not feel climate change at all. Our results indicate that $20 \%$ of 
the respondents wanted to participate in the development and implementation of an action plan for adaptation to climate change (questionnaire, question \#4). The participation of the population in preventing climate changes and in adaptation processes can take the following two directions: taking measures to minimize its negative environmental impact at the domestic level and manifesting its civic position through participation in projects, initiatives, actions at the local level.

According to the 2030 Agenda for Sustainable Development [19] the mission of city climate strategy should be to build a climate-responsible community and a climate-friendly urban environment. In the climatic strategy developed by us for the city of Zhytomyr, the implementation of the goal is realized through developing and implementing initiatives to reduce the vulnerability of human and natural systems of the city to the existing and potential effects of climate changes. The document mentioned above is under approval and consideration in the Zhytomyr city council. The Zhytomyr climate strategy project is a public document and is available for revision and updating. The content of this document is presented in Fig. 6 as a conceptual model of the city's climate strategy formation.

The conceptual model includes the obtained research results. It also comprises two trends of the climate policy - adaptation and prevention, which is consistent with the work of foreign colleagues $[1 ; 4]$. As a result of the research, we, as well as our colleagues $[2 ; 3]$, came to the conclusion that the process of recording the results and analyzing the effectiveness and efficiency of the implemented activities is a very important step. The above is possible to achieve through monitoring and control. The Zhytomyr climate strategy project identifies three main trends of the strategy - adaptation, monitoring/control, and prevention (the first block - trends).

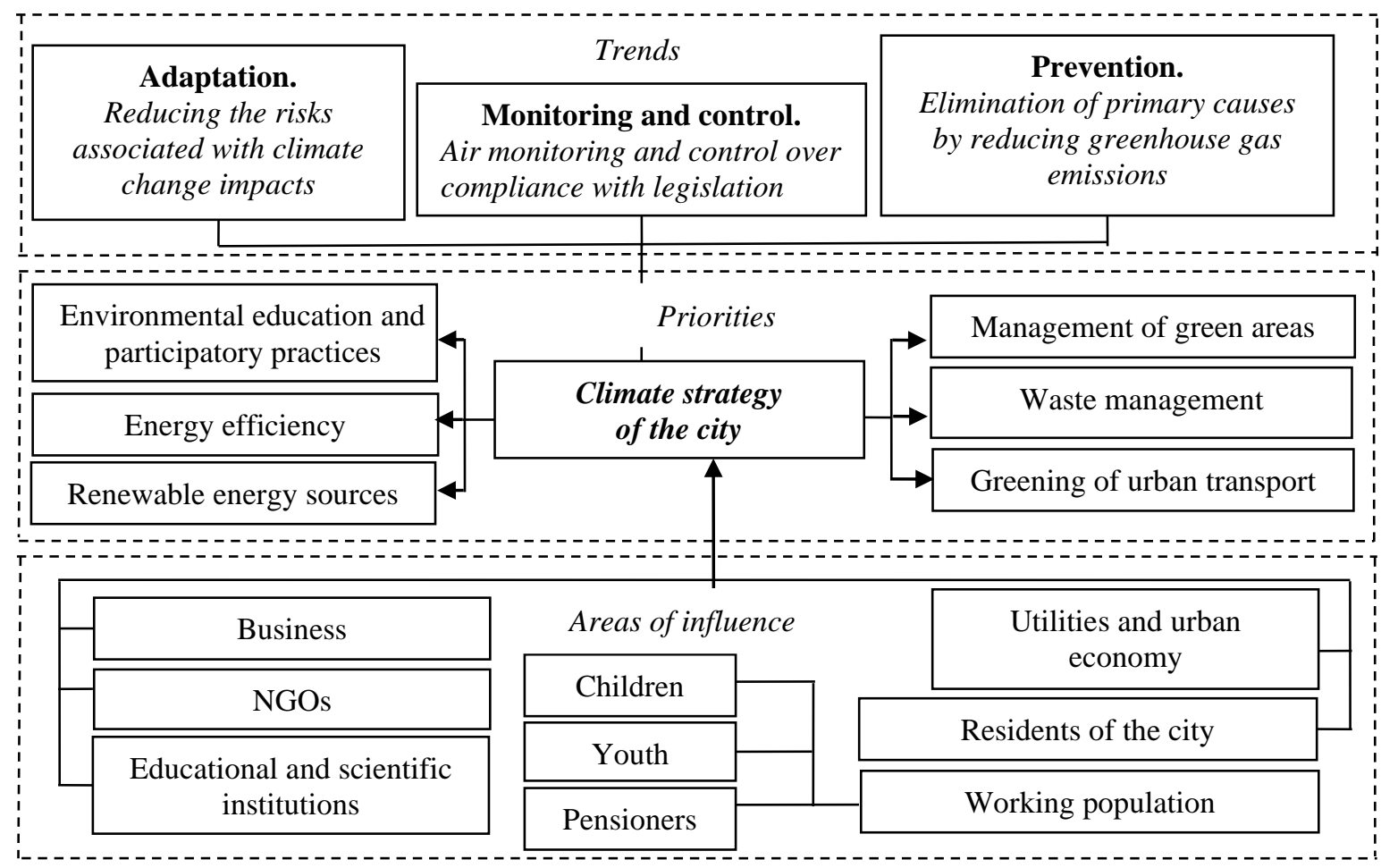

Fig. 6. Conceptual model of the city climate strategy formation

In the second block of the model (Fig. 6) the priorities are identified, each of which is directly related to the climate change issue. However, the main issue for the society is environmental education and participatory practices (the results of the survey). The importance of participatory practices is obvious. By feeling part of the strategy, people are content to pay more attention to prevention of climate changes, as well as to the adaptation process. Based on the proposed priorities, the document provides the main goals of the climate strategy: prevention and control over natural disasters, dangerous natural phenomena, emergencies; increasing the resilience of target ecosystems and sectors of the economy to real and potential impacts, and strengthening vulnerable population groups; overcoming the effects of past impacts and restoring damaged (altered) ecosystems. 
The third block of the model presents the spheres of influence (five groups) of the city's climate strategy in order to differentiate each approach. It should be noted that the development and implementation of a city climate policy is possible with active involvement of its community. Youth, especially students, is one of the most active and open parts of society ready for changes. That is why young people were identified as a separate group of stakeholders. Particular attention is paid, and the document emphasizes the need to involve students in the climate change adaptation measures. It is important to establish cooperation between students and representatives of local authorities.

The climate strategy project after approval and consideration in the Zhytomyr city council will be a basis of the climate strategy. The main point is that the shown model can be a universal practice for any Ukrainian city. According to the results of approbation, the stages of implementation of the strategy have been developed and given below.

The first stage of the process of development and implementation of the climate strategy is its initiation and research. This stage involves the initiation of the development of the city climate strategy and the determination of key directions for its implementation. We recommend constantly collecting information from stakeholders to monitor the situation in real-time. Speaking about the experience of Zhytomyr, this stage has been successfully passed. The priorities of the climate strategy were implemented into the integrated development "Strategy Zhytomyr 2030".

The next step is the direct development of a strategy that involves assessing the current state of the problem and conducting a SWOT analysis. At this stage, the plan of the city climate strategy is being prepared, defining the main stages, indicators and terms of implementation of the strategy.

The third stage is the adoption and implementation of the strategy. At this stage, a mechanism for implementing the strategy and adopting the city climate strategy at the level of local authorities is being developed. The process of strategy implementation begins.

The last stage is monitoring and control, which involves establishment of the monitoring system for implementation of the city climate strategy. Writing interim reports is an important step for the implementation of the strategy, in order to identify and eliminate errors, to review the indicators of strategy implementation, adjusting the strategy for new information.

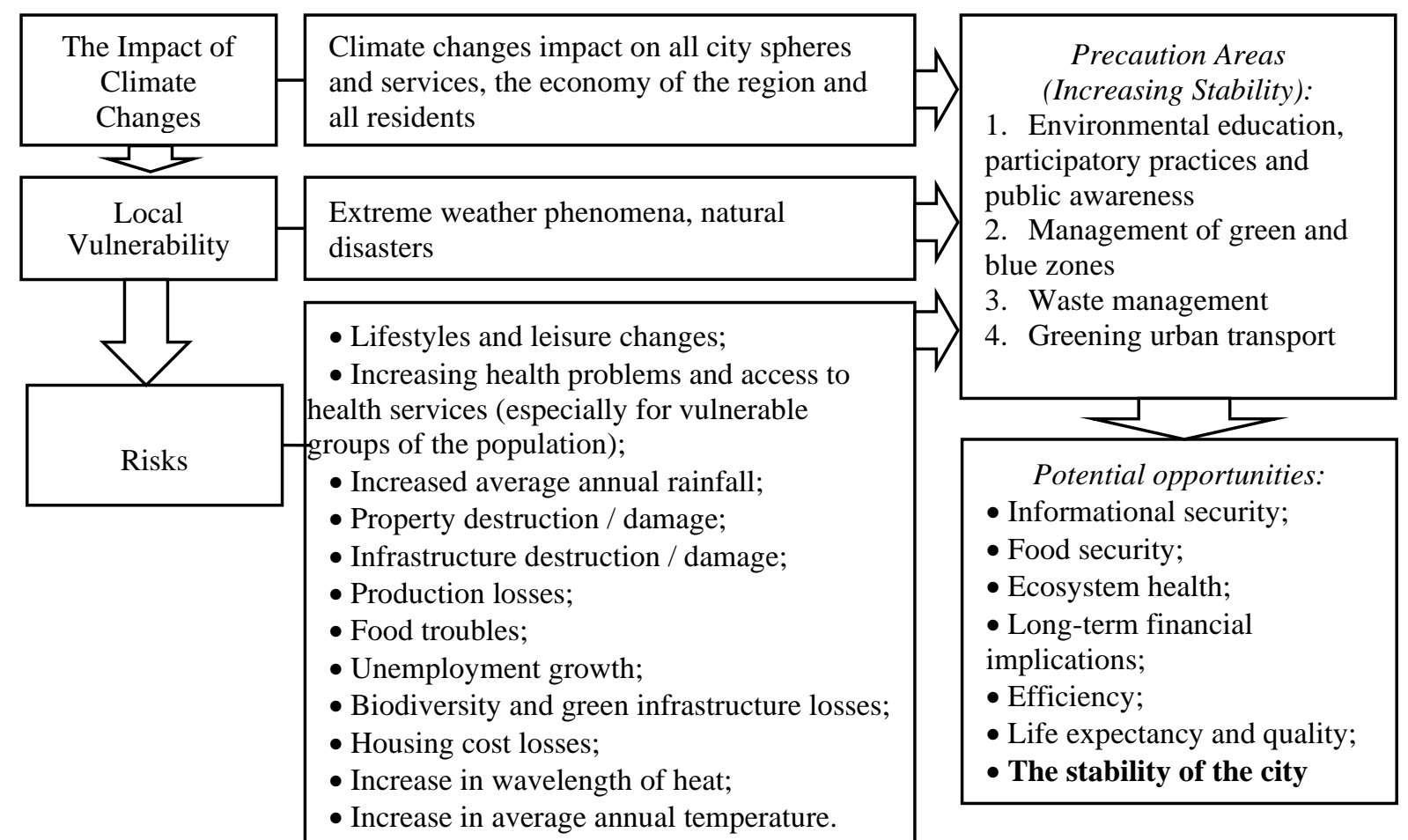

Fig. 7. Impact of climate changes on urban stability: risks and opportunities

At this stage, the control over the implementation of the measures provided by the document begins. Summing up the above, we can say that correct climate strategy can affect the stability of the city, and that is the goal of the municipal development (Fig. 7). 
When forming the climate strategy, it is very important to identify all risks that are relevant for the specific territory. Fig. 7 shows a list of risks that all regions of the world can encounter. It should be noted that the precaution area list could differ from one region to another.

Based on the results of our research, climate changes will affect and cause irreversible changes of all objects of nature, namely air, water, and soil. The city is much more vulnerable to climate change than other territories, which is confirmed by the works $[1-4 ; 20]$. Experts also confirm our opinion that it is more important to take care of urban dwellers' comfort [16]. Cities produce a big amount of greenhouse gasses. However, cities are not only the source of climate change, but also the place where innovative ideas are created in various fields of activity. Innovations play a significant and important role in the process of preventing climate changes and adaptation. When reducing the anthropogenic burden on the environment, it is necessary to meet the current growing needs of the population according to the postulates of sustainable development of society (stipulate the synergistic development of three systems: environmental, economic and social). The document that provides for the sustainable development of the city is the climate strategy.

\section{Conclusions}

1. According to the analysis of temperature changes in Zhytomyr in 2019, the average monthly temperature in June was $5.3{ }^{\circ} \mathrm{C}$ higher than the climatic norm, while there were 18 days with temperatures above $30{ }^{\circ} \mathrm{C}$. Winter temperature analysis (in December and February in 2019) was above the climatic norm by 5.4 and $5.8{ }^{\circ} \mathrm{C}$, respectively. That leads to the negative effects that reduce the comfort level of the city residents, which led to the development of the city's climate strategy.

2. The survey was conducted using a questionnaire consisting of four questions. The total number of respondents is 588 citizens. According to the first question, which determined the attitude of the population of Zhytomyr to climate change, it was found that $88 \%$ of the respondents are concerned about it. According to the question of the causes of climate change, $77 \%$ of the respondents are aware of the causes of climate change on the planet as a human activity. According to the question about the consequences of climate change felt by the inhabitants of Zhytomyr, most of the respondents pointed out the following: drought, damage to agriculture, natural disasters, lack of drinking water. According to the last question, only $20 \%$ of respondents were ready to participate in city actions for the adaptation to climate change.

3. Based on the Zhytomyr climate strategy project, a conceptual model of the city's climate strategy formation has been developed. It includes three stages of implementation: initiation and research; development of the strategy; adoption and implementation of the strategy; monitoring and control. The model can be a guide for writing the same strategic documents for other cities in Ukraine.

\section{References}

[1] Arnott J.C., Moser S.C., Goodrich K.A. Evaluation that counts: A review of climate change adaptation indicators \& metrics using lessons from effective evaluation and science-practice interaction. Environmental Science \& Policy, vol. 66, 2016, pp. 383-392, DOI: 10.1016/j.envsci.2016.06.017.

[2] Hughes S. Principles, drivers, and policy tools for just climate change adaptation in legacy cities. Environmental Science and Policy 111, 2020 DOI: 10.1016/j.envsci.2020.05.007

[3] Kleina J., Araosb M., Karimoc A., Heikkinend M., Ylä-Anttilac T., Juhola S. The role of the private sector and citizens in urban climate change adaptation: Evidence from a global assessment of large cities. Global Environmental Change Vol. 53, 2018, pp. 127-136

DOI: 10.1016/j.gloenvcha.2018.09.012

[4] Qazlbash S.K., Zubair M., Manzoor S.M., ul Haq A., Baloch M.S. Socioeconomic determinants of climate change adaptations in the flood-prone rural community of Indus Basin, Pakistan. Environmental Development 37, 2021 DOI: 10.1016/j.envdev.2020.100603

[5] IPCC, 2018: Summary for Policymakers. In: Global Warming of $1.5^{\circ} \mathrm{C}$ [online] [7.03.2021] Available at: https://www.ipcc.ch/sr15/ 
[6] Рамкова конвенція Організації Об'єднаних Націй про зміну клімату (United Nations Framework Convention on Climate Change) [online] [10.02.2021] Available at: https://zakon.rada.gov.ua/laws/show/995_044\#Text (In Ukrainian).

[7] Кіотський протокол до Рамкової конвенції Організації Об'єднаних Націй про зміну клімату (Kyoto Protocol to the United Nations Framework Convention on Climate Change) [online][ 10.02.2021] Available at: https://zakon.rada.gov.ua/laws/show/995_801\#Text (In Ukrainian).

[8] Паризька угода (The Paris Agreement) [online] [10.02.2021] Available at: https://zakon.rada.gov.ua/laws/show/995_161\#Text (In Ukrainian).

[9] Угода про асоціацію між Україною, 3 однієї сторони, та Європейським Союзом, Європейським співтовариством 3 атомної енергії і їхніми державами-членами, 3 іншої сторони (Association Agreement between Ukraine, of the one side, and the European Union, the European Atomic Energy Community and their Member States, of the other side) [online] [10.02.2021] Available at: https://zakon.rada.gov.ua/laws/show/984_011\#Text (In Ukrainian).

[10] Угода між Кабінетом Міністрів України та Європейським Співтовариством з атомної енергії про співробітництво у сфері мирного використання ядерної енергії (Agreement between the European Atomic Energy Community and the Cabinet of Ministers of Ukraine for Co-operation in the Peaceful Uses of Nuclear Energy) [online][ 10.02.2021] Available at: https://zakon.rada.gov.ua/laws/show/956_003\#Text (In Ukrainian).

[11] Концепція реалізації державної політики у сфері зміни клімату на період до 2030 року (Тhe concept of implementation of state policy in the field of climate change for the period up to 2030) [online] [ 10.02.2021] Available at: https://zakon.rada.gov.ua/laws/show/932-2016-\%D1\%80\#Text (In Ukrainian).

[12] Рішення Львівської міської ради № 934 Про погодження Комплексу першочергових заходів щодо покращання якості повітря у м. Львові (Decision of the Lviv City Council № 934 On approval of the Complex of priority measures to improve air quality in Lviv) [online][ 10.02.2021] Available at: https://www8.cityadm.lviv.ua/Pool/Info/doclmr_1.NSF/(SearchForWeb)/64D204BFDB42AB2FC2258603003A9F7 8? OpenDocument (In Ukrainian).

[13] Lemos M.C., Wolske K.S., Rasmussen L.V., Arnott J.C., Kalcic M., Kirchhoff C.J. The Closer, the Better? Untangling Scientist-Practitioner Engagement, Interaction, and Knowledge Use. Weather, Climate, and Society, vol. 11, 2019, pp. 535-548, DOI: 10.1175/WCAS-D-18-0075.1

[14] Moss R.H., and coauthors Evaluating Knowledge to Support Climate Action: A Framework for Sustained Assessment. Report of an Independent Advisory Committee on Applied Climate Assessment. Weather, Climate, and Society, vol. 11, 2019, pp. 465-487, DOI: 10.1175/WCAS-D$18-0134.1$

[15] Hackenbruch J., Kunz-Plapp T., Müller S., Schipper J.W. Tailoring Climate Parameters to Information Needs for Local Adaptation to Climate Change. Climate, 2017, vol. 5(2), 25, DOI: $10.3390 /$ cli5020025

[16] Гейл Я. Міста для людей (Cities for People) Island Press, 2010, 288 p. (In Ukrainian)

[17] Малхотра Н. Маркетинговые исследования : практ. руководство (Marketing Research: An Applied Approach). 5 edn, 2007, 1200 p. (In Russian)

[18] Моосмюллер Г. Маркетинговые исследования с SPSS : учебное пособие (Marketing research with SPSS: a textbook) INFRA-M, Moskau, 2009, 160 p.

[19] Transforming our world: the 2030 Agenda for Sustainable Development. Resolution adopted by the General Assembly on 25 September 2015, 35 p.

[20] Shevchenko O., Oliinyk R., Snizhko S., Svintsitska H., Kostyrko I. Indexing of Heatwaves in Ukraine. Water. 12. 962, 2020 DOI:10.3390/w12040962 